\title{
Pengaruh Metode Bercerita dan Gaya Belajar terhadap Kemampuan Berbicara Anak usia dini
}

\author{
Monica Hotma Elya \\ Pendidikan Anak Usia Dini, Universitas Negeri Jakarta \\ DOI: $10.31004 /$ obsesi.v4i1.326
}

\begin{abstract}
Abstrak
Tujuan dari penelitian ini adalah untuk memperoleh data secara empiris dan gambaran tentang pengaruh metode bercerita dan gaya balajar terhadap kemampuan berbicara anak. Penelitian ini menggunakan pendekatan kuantitatif dengan menggunakan metode eksperimen dengan rancangan factorial design $2 x 2$, dengan variabel terikat dalam penelitian ini adalah kemampuan berbicara anak sedangkan variabel bebasnya adalah metode bercerita yang terdiri dari 2 (dua) taraf yaitu media boneka tangan dan media power point dan variabel atribut adalah gaya belajar yang terdiri dari 2 (dua) taraf yaitu auditory dan visual. Sampel dalam penelitian ini yaitu anak kelas A dan B di Taman Kanak-Kanak IPEKA Sunter 1 Jakarta Utara tahun pelajaran 2018/2019 sebanyak 44 orang. Hasil penelitian ini menunjukan bahwa terdapat pengaruh yang signifikan pada metode bercerita dan gaya belajar terhadap kemampuan berbicara anak.
\end{abstract}

Kata Kunci: berbicara; gaya belajar; kemampuan berbicara anak.

\begin{abstract}
The purpose of this study is to obtain empirical data and an overview of the influence of storytelling methods and the learning style of children's speaking skills. This study used quantitative approaches using experimental methods with factorial design $2 \times 2$ designs, with variables tied to the study being the ability to speak children while the free variables are methods of storytelling consisting of 2 (two) levels i.e. hand puppet media and media Power point and attribute variables is a learning style consisting of 2 (two) levels namely auditory and visual. Samples in this study are children A and B grades in the kindergarten IPEKA Sunter 1 North Jakarta year 2018/2019 lesson as many as 44 people. The results showed that there was a significant influence on the method of storytelling and the learning style of the child's speaking ability.
\end{abstract}

Keywords: speaking, learning styles, children's speaking abilities.

Copyright (c) 2019 Monica Hotma Elya

$\triangle$ Corresponding author:

Email Address : monicaelya_paud15s2@mahasiswa.unj.ac.id (Rawamangun, Jakarta)

Received 16 November 2019, Accepted 26 November 2019, Published 29 November 2019

\section{PENDAHULUAN}

Pendidikan anak usia dini adalah pendidikan pertama kali yang diberikan kepada anak dalam rangka membentuk mereka menjadi manusia sempurna dan paripurna di masa yang akan datang. Sehingga sebagai jenjang pendidikan pertama yang diberikan kepada anak, di luar pendidikan informal yang dilakukan oleh kedua orang tua di rumah, maka sudah barang tentu Pendidikan Anak Usia Dini (PAUD) membutuhkan perhatian yang 
DOI: 10.31004 /obsesi.v4i1.326

serius dalam pengimplementasiannya. Menurut Eliza dalam (Nengsi \& Eliza, 2019) pendidikan anak usia dini merupakan pendidikan yang amat penting untuk anak dikehidupan selanjutnya. Kualitas pengalaman yang diperoleh anak di waktu usia dini akan menjadikan lebih bermakna untuk mencapai masa depannyaKeseriusan secara holistik dilakukan dalam semua aspek atau komponen pendidikan mulai dari tahap perencanaan, pelaksanaan sampai pada tahap evaluasi. Sebab pada konteks jenjang pendidikan anak usia dini, yang menjadi subjek didik adalah anak usia 0 sampai 6 tahun yang juga familiar dikenal dengan masa balita. Pembinaan dalam pendidikan anak usia dini dilakukan untuk membantu pertumbuhan dan perkembangan jasmani dan rohani agar memiliki kesiapan dalam menghadapi tugas perkembangan selanjutnya.(Sumarsih, Nurmalina, \& Astuti, 2018)

Masa balita disebut sebagai masa emas karena pada usia ini perkembangan otak berjalan sangat cepat, sementara tumbuh kembang lainnya juga berlangsung pesat. Oleh karena itu, masa ini merupakan saat yang tepat untuk mengoptimalkan tumbuh kembang anak melalui stimulasi pendidikan dan metode pengajaran, pola pengasuhan yang baik, pemberian asupan gizi yang cukup serta pemantauan dan perawatan kesehatan anak secara berkelanjutan. Olehnya itu penyelenggaraan pendidikan harus dilaksanakan secara holistik integratif demi tumbuh kembang anak. Menurut Hasan (2010) menyatakan bahwa salah satu hal yang berpengaruh terhadap kemandirian anak adalah pola pengasuhan orang tua.(Affrida, 2017)

Terkait dengan kualitas Sumber Daya Manusia (SDM), yang antara lain dicerminkan oleh derajat kesehatan, kematangan emosional dan spiritual serta tingkat intelegensia yang di dalamnya termasuk kemampuan berbicara anak yang ditentukan oleh kualitas anak sejak janin dalam kandungan hingga anak berusia 6 tahun. Pada periode ini seorang anak sangat membutuhkan asupan gizi yang seimbang, kesehatan, dan pengasuhan serta pola pedidikan dan metode pengajaran yang baik dan benar agar anak dapat tumbuh kembang secara optimal. Oleh karena itu dalam menciptakan SDM yang bermutu, perlu dilakukan sejak dini yaitu sejak Taman Kanak-Kanak (TK) dengan memenuhi kebutuhan dasar anak.

Di Indonesia kita bisa mendapatkan jenis layanan PAUD berdasarkan usia anak yaitu layanan PAUD yang pertama ialah Taman penitipan anak (TPA) untuk anak berusia dari tiga bulan- dua tahun, kemudian Kelompok bermain (KB) yaitu layanan yang diberikan kepada anak yang berusia dua tahun sampai empat tahun, layanan selanjutnya ialah Taman kanak-kanak atau TK ialah layanan yang diberikan kepada anak yang berumur 5-6 tahun. (Hasanah \& Muryanti, 2019) Taman Kanak-kanak adalah salah satu bentuk satuan PAUD pada jalur pendidikan formal yang menyelenggarakan program pendidikan bagi anak usia empat tahun sampai enam tahun dan berfungsi untuk mengenalkan peraturan dan menanamkan disiplin pada anak, mengenalkan anak pada dunia sekitar, menumbuhkan sikap dan perilaku yang baik, mengembangkan kemampuan berkomunikasi dan bersosialisasi, mengembangkan keterampilan, kreativitas, dan kemampuan yang dimiliki anak serta menyiapkan anak untuk memasuki pendidikan dasar. TK harus mengembangkan lima aspek perkembangan. Aspek-aspek itu adalah aspek nilai-nilai agama dan moral, aspek sosial-emosional, aspek fisik-motorik, aspek kognitif, dan aspek bahasa. Masing-masing aspek perkembangan harus dikembangkan secara optimal. Salah satu aspek yang penting untuk dikembangkan adalah aspek bahasa yang meliputi kemampuan berbicara anak. Anak usia dini ini memiliki ragam aspek perkembangan diantaranya ada aspek kognitif, fisik motorik,sosial emosional seni, , nilai agama moral dan bahasa.(Hasanah \& Muryanti, 2019)

Bahasa adalah bentuk komunikasi yang diucapkan, ditulis, atau dilambangkan berdasarkan sistem simbol. Bahasa digunakan untuk berkomunikasi. Senada dengan hal tersebut, program pengembangan bahasa di Taman Kanak-kanak bertujuan agar anak mampu mengungkapkan pikiran melalui bahasa yang sederhana secara tepat, mampu berkomunikasi secara efektif, serta membangkitkan minat untuk dapat berbahasa dengan baik dan benar. Aspek pengembangan bahasa anak usia dini meliputi mendengarkan, 
berbicara, membaca, dan menulis. Dalam hal ini penulis menitikberatkan pada aspek pengembangan kemampuan berbicara. Bicara merupakan alat yang digunakan untuk mengungkapkan perasaan atau maksud kepada orang lain. Keterampilan berbicara merupakan kemampuan yang sangat mendasar untuk berinteraksi dan berkomunikasi dengan lingkungan, dimana dengan memiliki kosakata yang banyak maka anak dapat berbicara dengan baik dan lancar.

Berbicara mencakup tiga proses terpisah tetapi saling berkaitan satu sama lain, yaitu belajar pengucapan kata, membangun kosakata, dan membentuk kalimat. Mengembangkan keterampilan bicara tidak bisa hanya dengan mengandalkan keaktifan guru atau teacher centered saja tetapi anak harus terlibat aktif dalam kegiatan pembelajaran tersebut atau student centered. Keterampilan bicara akan meningkat jika anak mengalami bicara itu sendiri, dengan kata lain anak belajar saat mengalami. Maka untuk mengembangkan keterampilan bicara dibutuhkan metode yang menuntut anak untuk terlibat aktif di dalamya. Dalam hal ini penulis menggunakan metode bercerita yang meliputi metode bercerita dengan media boneka tangan dan metode bercerita dengan media power point. Dengan menggunakan kedua metode bercerita tersebut, anak akan dapat terlibat aktif di dalam proses pembelajaran, sebab proses pembelajaran yang menggunakan metode bercerita dengan media boneka tangan menuntut anak untuk dapat mengulang kembali isi cerita yang telah disampaikan oleh guru sekaligus mempraktikkan atau memainkan secara langsung media boneka tangan yang telah dipersiapkan. Begitu pula dengan media power point dalam bentuk animasi yang menampilkan isi cerita bergambar (audio-visual), di samping dapat menarik perhatian anak dalam mendengar dan/atau menyimak isi cerita, media ini juga dianggap efektif untuk meningkatkan kemampuan berbicara anak, sebab kombinasi audio visual membuat anak dapat menyimak isi cerita yang disampaikan. Membandingkan kedua metode bercerita ini dengan memberikan perlakuan (treatment) kepada anak diharapkan dapat diperoleh informasi keilmuan tentang efektivitas pengaruhnya terhadap kemampuan berbicara anak.

Pendidikan di Taman Kanak-kanak pada dasarnya adalah pembelajaran yang sederhana dan konkret sesuai dengan dunia kehidupan anak, terkait dengan situasi pengalaman langsung, kreatif, menyenangkan dan menarik, mengundang rasa ingin tahu, bermanfaat dan terkait dengan aktivitas-aktivitas bermain anak. Kemampuan berbicara yang baik serta terarah harus ditanamkan pada anak sedini mungkin melalui proses pembelajaran di sekolah dengan menggunakan metode dan media pembelajaran yang menarik sesuai dengan gaya belajar anak, karena bahasa lisan yang disampaikan melalui berbicara adalah alat untuk menyatakan fikiran dan perasaan sekaligus alat komunikasi antar manusia. Tidak sedikit orang tua, anggota keluarga dan guru di sekolah yang tidak memahami perkataan yang disampaikan oleh anak. Sehingga membuat anak merasa kurang mendapatkan perhatian dikarenakan tidak semua yang diinginkan oleh anak mampu dipenuhi sesuai dengan harapan anak. Padahal masalah ini terjadi karena anak kurang atau tidak mampu menyampaikan keinginannya dengan baik. Begitu pula dalam konteks hubungan interaksi sosial dengan teman-teman sejawatnya.

Menurut Depdikbud bicara secara umum dapat diartikan suatu penyampaian maksud (ide, pikiran, gagasan, atau isi hati) seseorang kepada orang lain dengan menggunakan bahasa lisan sehingga maksud tersebut dapat dipahami orang lain (Suhartono, 2010). Tarigan menyatakan bahwa bicara adalah kemampuan mengucapkan bunyi-bunyi artikulasi atau kata-kata untuk mengekspresikan, menyatakan serta menyampaikan pikiran, gagasan, dan perasaan (Suhartono, 2010). Selanjutnya Hariyadi dan Zamzami juga mengungkapkan bahwa berbicara pada hakikatnya merupakan suatu proses berkomunikasi, sebab di dalamnya terjadi pesan dari suatu sumber ke tempat lain (Suhartono, 2010).

Hurlock menyatakan bahwa berbicara tidak hanya melibatkan koordinasi kumpulan otot mekanisme suara yang berbeda, tetapi juga mempunyai aspek mental yakni 
DOI: 10.31004 /obsesi.v4i1.326

kemampuan mengkaitkan arti dengan bunyi yang dihasilkan (Hurlock, 1978). Meskipun demikian tidak semua bunyi yang dihasilkan anak dapat dipandang sebagai bicara. Ada dua kriteria yang dapat digunakan untuk memutuskan apakah anak berbicara dalam artian yang benar atau hanya "membeo". Kriteria itu adalah pertama, anak harus mengetahui arti kata yang digunakannya dan mengkaitkannya dengan objek yang diwakilinya. Kedua, anak harus melafalkan kata-katanya sehingga orang lain memahaminya dengan mudah. Anak belum dikatakan berbicara apabila anak tidak mengetahui arti kata yang digunakannya.

Dari beberapa definisi tersebut dapat disimpulkan bahwa keterampilan berbicara adalah proses berkomunikasi dengan mengucapkan bunyi-bunyi artikulasi untuk menyampaikan maksud sehingga maksud tersebut dapat dipahami oleh orang lain. Proses berkomunikasi agar mudah dipahami maka kata yang diucapkan tentunya harus jelas dan lancar. Anak dikatakan keterampilan bicaranya meningkat apabila anak dapat melafalkan bunyi bahasa yang digunakan secara tepat, pengucapan suku kata yang berbeda-beda dan diucapkan secara jelas, anak mempunyai perbendaharaan kata yang memadai untuk keperluan berkomunikasi, serta mampu menggunakan kalimat secara baik untuk berkomunikasi secara lisan.

Suhartono mengemukakan bahwa perkembangan bicara adalah perkembangan bicara yang berhubungan dengan fonologi, morfologi, sintaksis, dan sematik (Suhartono, 2010). Selanjutnya Steinberg dan Gleason membagi perkembangan bahasa (termasuk bicara) ke dalam tiga tahap yakni perkembangan bicara prasekolah, tahap perkembangan bicara kombinatori, dan tahap perkembangan bicara masa sekolah (Suhartono, 2010).

Steinberg dan Gleason mengemukakan bahwa perkembangan bicara anak prasekolah disebut juga perkembangan bahasa anak sebelum memasuki sekolah (Suhartono, 2010). Perkembangan bicara anak prasekolah itu sendiri meliputi tahap penamaan, tahap telegrafis, dan tahap transformasional. Tahap penamaan yaitu anak baru mulai mampu mengujarkan urutan bunyi kata tertentu dan belum mampu untuk memaknainya. Tahap selanjutnya adalah tahap telegrafis yaitu anak sudah mulai bisa menyampaikan pesan yang diinginkannya dalam bentuk urutan bunyi yang berwujud dua atau tiga kata. Jika dalam tahap penamaan anak hanya mengucapkan urutan kata tanpa mengetahui maknanya, maka dalam tahap telegrafis anak sudah mengucapkan urutan kata dan mengetahui maknanya. Sedangkan tahap transformasional yaitu anak sudah mampu mentransformasikan apa yang ada dalam pikirannya dalam berbagai jenis kalimat. Jadi anak sudah mampu menyampaikan apa yang ada dalam pikirannya dalam bentuk urutan kata atau kalimat.

Tahap perkembangan bicara yang selanjutnya adalah tahap perkembangan bicara kombinatori. Steinberg dan Gleason, mengemukakan bahwa tahap perkembangan bicara kombinatori pada umumnya terjadi pada anak usia 3-5 tahun. Pada tahap perkembangan bicara kombinatori ini anak sudah mampu menggunakan bahasa dalam bentuk negatif, interogatif, dan mampu juga menggabungkan preposisi menjadi satu kalimat tunggal. Pada tahap perkembangan kombinatori ini anak juga sudah mulai mampu berbicara secara teratur dan terstruktur. Bicara anak dapat dipahami oleh orang lain dan anak sanggup merespon baik positif maupun negatif atas pembicaraan lawan bicaranya. Bahasa yang digunakannya menunjukkan aturan atau tata bahasa sendiri (Suhartono, 2010).

Tahap perkembangan bicara yang terakhir adalah tahap perkembangan bicara masa sekolah. Steinberg dan Gleason, mengemukakan bahwa perkembangan bicara masa sekolah meliputi perkembangan pragmatik; perkembangan bicara sematik dan kosakata; serta perkembangan morfologi dan sintaksis. Perkembangan pragmatik adalah perkembangan anak usia sekolah dalam menggunakan bahasa lisan (bicara) sesuai dengan konteks secara komunikatif. Dalam berbicara anak sudah mulai memperhatikan siapa lawan bicaranya, di mana bicaranya, media apa yang digunakan, dan dalam situasi apa. Selanjutnya dalam perkembangan sematik dan kosakata anak akan berusaha untuk 
meningkatkan jumlah kosakata dan berusaha memahami maknanya. Sementara perkembangan morfologi dan sintaktis adalah perkembangan bicara anak sekolah dalam bicara kaitannya dengan pemahaman susunan dan bentuk bahasa (Suhartono, 2010).

Vygotsky menyatakan bahwa ada tiga tahap perkembangan bicara yang menentukan tingkat perkembangan berpikir dengan bahasa yaitu tahap eksternal, egosentris, dan internal. Tahap pertama, tahap eksternal merupakan tahap berpikir dengan bahasa yang disebut berbicara secara eksternal. Maksudnya, sumber berpikir anak datang dari luar dirinya. Sumber itu terutama berasal dari orang dewasa yang memberi pengarahan anak dengan cara tertentu misalnya orang dewasa bertanya kepada anak. Tahap kedua, yaitu tahap egosentris merupakan tahap di mana pembicaraan orang dewasa tidak lagi menjadi persyaratan. Dengan suara khas anak berbicara seperti jalan pikirannya. Tahap ketiga, merupakan tahap berbicara secara internal. Di sini anak menghayati sepenuhnya proses berpikirnya. Pada tahap ini anak memproses pikirannya dengan pemikirannya sendiri ( $R, 2011)$.

Jalongo mengelompokkan perkembangan bahasa anak tahap pralinguistik dan linguistik. Tahap pralinguistik dimulai sejak lahir sampai usia 11 bulan, sedangkan periode linguistik berada pada tahap suku kata di mana anak hanya mengulang kata yang telah didengarnya (Zubaidah, 2013).

Dari berbagai teori tentang tahap perkembangan bicara dapat disimpulkan bahwa anak usia 4-5 tahun sudah mampu menggabungkan preposisi menjadi satu kalimat tunggal, kalimat yang diucapkan sudah mulai teratur dan terstruktur. Anak telah mampu untuk memahami dan melahirkan apa yang orang sampaikan ke anak ataupun apa yang ingin disampaikannya ke orang lain. Perbendaharaan kata 1.400-1.600 kata, susunan kalimat dan tata bahasa yang benar, menggunakan awalan; kata kerja sekarang, kemarin, dan akan datang; rata-rata panjang kalimat perkalimat meningkat menjadi 6-8 kata, kosakata menggunakan kira-kira 2.500 kata, mengerti sekitar 6.000 kata, dan respon 25.000 kata.

Dari hasil observasi yang dilakukan pada tanggal 7 Desember 2018 di Taman Kanak-Kanak IPEKA Sunter 1 Jakarta Utara kenyataan (reality) yang terjadi menunjukkan bahwa masih terdapat anak didik yang kemampuan berbicaranya rendah sehingga mereka tidak dapat menyampaikan secara langsung apa yang mereka butuhkan baik yang berhubungan dengan pembelajaran di dalam kelas, maupun aktivitas di luar kelas. Saat anak diminta untuk menceritakan pengalaman atau kejadian di depan kelas, ada 13 dari 17 anak yang tidak mampu menceritakan pengalaman/kejadian itu secara urut dan runtut. Anak akan menunggu stimulasi berupa pertanyaan dari guru. Selain itu anak juga belum mampu untuk menjawab dan menceritakan kembali isi cerita yang telah disampaikan guru. Kemampuan anak dalam menjawab ataupun menceritakan kembali isi cerita yang dibawakan guru, sebagian besar belum mampu menjabarkannya dengan benar. Anak hanya akan mengucapkan satu atau dua kata saja, bukan berupa kalimat. Hal itu disebabkan karena pada saat menceritakan kembali isi cerita, anak kekurangan bahan yang akan diceritakannya. Selain itu, anak sering lupa dengan kalimat apa yang diucapkan guru saat bercerita. Hal ini menunjukkan bahwa keterampilan bicara anak pada kelas A dan B di Taman Kanak-Kanak IPEKA Sunter 1 Jakarta Utara belum berkembang secara optimal. Keadaan ini tentunya menjadi perhatian yang serius khususnya oleh guru dan juga sekolah. Perlu adanya pemberian perlakuan yang tepat di dalam proses pembelajaran dengan tujuan untuk meningkatkan kemampuan berbicara anak. Pemberian metode pembelajaran yang tepat dibantu dengan media pembelajaran kreatif dan inovatif yang disesuaikan dengan gaya belajar anak diharapkan dapat membantu meningkatkan kemampuan berbicara bagi anak.

Permasalahan di Taman Kanak-Kanak IPEKA Sunter 1 Jakarta Utara sebagaimana yang telah disebutkan di atas tidak terlepas dari penggunaan metode dan media yang kurang tepat dalam mengembangkan keterampilan berbicara. Metode dan media yang digunakan biasanya kurang menarik bagi anak. Dalam mengembangkan keterampilan 
DOI: $10.31004 /$ obsesi.v4i1.326

bicara anak akan lebih efektif jika menggunakan media yang tepat. Dengan metode dan media pembelajaran yang tepat keterampilan bicara anak akan berkembang dengan baik. Selain itu dibutuhkan metode dan media yang dapat merangsang dan mengingat kembali cerita yang dibawakan guru. Dengan begitu anak mempunyai bahan yang akan diceritakan kembali. Sebenarnya secara teoretik ada banyak metode dan media pembelajaran yang cocok dan dapat digunakan untuk diterapkan dalam pembelajaran di Taman Kanak-kanak bagi anak usia dini. Salah satu metode pembelajaran yang dapat diberikan kepada anak usia dini adalah metode bercerita dengan menggunakan media boneka tangan dan media power point.

Metode bercerita dengan media boneka tangan merupakan media yang menarik bagi anak. Selain itu boneka tangan ini juga digunakan langsung oleh anak. Boneka tangan ini dapat digunakan untuk memerankan suatu tokoh dalam cerita. Pada saat anak menceritakan kembali cerita yang dibawakan guru, boneka tangan ini dapat merangsang dan dapat membantu mengingat kembali isi cerita. Metode bercerita salah satu kegemaran anak-anak adalah mendengarkan cerita. Melalui cerita seorang guru dapat menerapkan nilai-nilai keagamaan kepada anak. Cerita yang dibawakan hendaknya yang berhubungan dengan dunia anak-anak sehinga akan lebih menarik minat mereka untuk mendengarkan.(Ananda, 2017) sedangkan JR, Luthfi, \& Fauziddin ( 2018) menjelaskan Metode bercerita merupakan cara atau media yang digunakan pendidik untuk menyampaikan atau menyajikan materi pembelajaran yang disampaikan secara lisan dalam bentuk cerita yang menarik kepada anak. Selanjutya dengan bercerita akan menimbulkan kesan pada diri anak. Penyampaian pesan moral yang terkandung dalam cerita akan lebih mudah melekat didalam benak anak- anak, karena dengan metode bercerita dinilai lebih menarik dan berkesan bagi anak.(Pebriana, 2017)

Diketahui bahwa signifikasi pengaruh atas penggunaan metode dan media pembelajaran terhadap kemampuan berbicara anak akan dapat diperoleh apabila penggunaannya dapat disesuaikan dengan gaya belajar anak. Secara konseptual dan teoretik, gaya belajar anak dibagi menjadi 3 (tiga) yaitu auditori, kinestetik dan visual. Guna kepentingan peningkatan kemampuan berbicara anak di Taman Kanak-Kanak IPEKA Sunter 1 Jakarta Utara pada Tahun Ajaran 2018/2019, maka perlu dilakukan penelitian eksperimen yang secara umum tujuannya adalah untuk meningkatkan kemampuan berbicara anak dengan membandingkan (mengkomparasikan) antara metode bercerita menggunakan media boneka tangan dan metode bercerita menggunakan media power point dengan gaya belajar anak. Olehnya itu, berdasarkan uraian di atas peneliti tertarik untuk mengangkat judul penelitian pada tesis ini yaitu "Pengaruh Metode Bercerita dan Gaya Belajar Terhadap Kemampuan Berbicara Anak (Penelitian Eksperimen di Taman KanakKanak IPEKA Sunter 1 Jakarta Utara Tahun Ajaran 2018/2019).

\section{METODOLOGI}

Penelitian dilakukan dengan menggunakan metode eksperimen yang melibatkan variabel terikat $(\mathrm{Y})$, variabel bebas $(\mathrm{A})$ dan variabel atribut atau moderator (B). Variabel terikatnya adalah kemampuan berbicara anak. Variabel bebasnya yaitu metode bercerita yang terdiri dari 2 (dua) taraf yaitu metode bercerita dengan media boneka tangan dan metode bercerita dengan media power point. Sedangkan variabel atribut atau moderator yaitu gaya belajar yang terdiri dari 2 (dua) taraf yaitu gaya belajar auditory dan visual. Jadi penelitian ini akan membandingkan atau mengkomparasikan 2 (dua) metode bercerita yang berbeda yaitu metode bercerita dengan media boneka tangan dan metode bercerita dengan media power point dengan variabel moderator atau atribut gaya belajar anak untuk melihat kemampuan berbicara anak di Taman Kanak-Kanak IPEKA Sunter 1 Jakarta. Desain penelitian yang digunakan dalam penelitian ini adalah desain eksperimen dengan rancangan factorial design $2 \times 2$. 
Populasi target dalam penelitian ini adalah seluruh anak usia dini pada jenjang pendidikan Taman Kanak-Kanak se Jakarta Utara tahun pelajaran 2018/2019. Populasi terjangkau adalah seluruh anak usia dini yang terdapat di Taman Kanak-Kanak IPEKA Sunter 1 Jakarta Utara Tahun Ajaran 2018/2019.

Sampel dalam penelitian ini yaitu anak kelas A dan B di Taman Kanak-Kanak IPEKA Sunter 1 Jakarta Utara tahun pelajaran 2018/2019. Dalam penelitian ini, teknik pengambilan sampel dilakukan dengan teknik multi stage simple random sampling, yang meliputi: 1) mengumpulkan nama-nama Taman Kanak-Kanak yang ada di Kota Jakarta Utara, kemudian melakukan simple random sampling terhadap nama-nama Taman Kanak-Kanak tersebut; 2) menetapkan 1 sekolah Taman Kanak-Kanak terpilih untuk dijadikan tempat penelitian, kemudian melakukan simple random sampling kembali untuk menentukan kelas eksperimen; 3) terpilih Taman Kanak-Kanak IPEKA Sunter 1 Jakarta Utara pada kelas A dan B, setelah selesai melakukan simple random sampling sekolah Taman Kanak-Kanak pada kelas A dan B dilanjutkan dengan melakukan simple random sampling untuk menentukan metode bercerita di Taman Kanak-Kanak IPEKA Sunter 1 Jakarta Utara sehingga ditetapkan bahwa untuk metode bercerita dengan media boneka tangan akan diterapkan atau dilaksanakan di kelas A Taman Kanak-Kanak IPEKA Sunter 1 Jakarta Utara dan metode bercerita dengan media power point diterapkan atau dilaksanakan di kelas B Taman Kanak-Kanak IPEKA Sunter 1 Jakarta Utara. Adapun keseluruhan jumlah anak pada 2 (dua) kelas Taman Kanak-Kanak IPEKA Sunter 1 Jakarta Utara adalah 68 orang anak dengan pembagian 34 orang anak di kelas A dan 34 orang akan di kelas B Taman Kanak-Kanak IPEKA Sunter 1 Jakarta Utara.

Peneliti mengambil 33\% kelompok atas yang memperoleh skor tertinggi sebagai kelompok atas dan 33\% kelompok anak yang memperoleh skor terendah sebagai kelompok bawah. Sehingga anak yang memperoleh skor di tengah distribusi, datanya dikeluarkan dan tidak dianalisis. Namun demikian, anak yang tidak termasuk dalam subyek penelitian tersebut tetap mendapat pelayanan yang sama dengan anak yang dijadikan subyek penelitian pada kelas eksperimen. Jumlah anak kelas A dan kelas B Taman Kanak-Kanak IPEKA Sunter 1 Jakarta Utara secara keseluruhan sebanyak 68 orang yang tersebar dalam dua kelas. Dengan demikian maka jumlah anggota sampel pada setiap kelompok yang dijadikan sebagai unit analisis sesuai dengan desain penelitian ini sebanyak 44 orang. Dari jumlah 44 (empat puluh empat) anak terbentuk 4 (empat) sel dari kedua kelompok metode bercerita yakni: (1) Kelompok metode bercerita dengan menggunakan media boneka tangan yang memiliki gaya belajar auditory dengan jumlah sampel 11 anak $\left(\mathrm{A}_{1} \mathrm{~B}_{1}\right)$, (2) Kelompok metode bercerita dengan menggunakan media power point yang memiliki gaya belajar auditory dengan jumlah sampel 11 anak $\left(\mathrm{A}_{2} \mathrm{~B}_{1}\right)$, (3) Kelompok metode bercerita dengan menggunakan media boneka tangan yang memiliki gaya belajar visual dengan jumlah sampel 11 anak $\left(\mathrm{A}_{1} \mathrm{~B}_{2}\right)$, dan (4) Kelompok metode bercerita dengan menggunakan media power point yang memiliki gaya belajar visual dengan jumlah sampel 11 anak $\left(\mathrm{A}_{2} \mathrm{~B}_{2}\right)$.

Penelitian ini dilaksanakan di Taman Kanak-Kanak IPEKA Sunter 1 Jakarta Utara Tahun Ajaran 2018/2019 yang merupakan representasi Taman Kanak-Kanak yang terdapat di Jakarta Utara. Sebagai objek penelitian adalah anak usia dini kelas A dan B. Penelitian ini dilaksanakan sesuai dengan jadwal Rencana Kegiatan Harian (RKH) Taman Kanak-Kanak IPEKA Sunter 1 Jakarta Utara. Penelitian ini akan dilaksanakan pada semester ganjil selama dua bulan atau 8 (delapan) minggu dengan frekuensi perlakuan dua kali seminggu. Jadi secara keseluruhan jumlah pertemuan adalah sebanyak 16 kali pertemuan. Dengan rincian kegitan meliputi: (1) Pelaksanaan observasi awal untuk pengambilan data yaitu observasi untuk mengetahui gaya belajar anak sebagai dasar pengelompokan sampel penelitian, (2) Pelaksanaan eksperimen tentang metode bercerita dengan menggunakan media boneka tangan dan media power point, dan (3) Pelaksanaan observasi akhir yaitu untuk memperoleh data mengenai kemampuan berbicara anak. 
DOI: 10.31004 /obsesi.v4i1.326

Data yang dikumpulkan dalam penelitian ini adalah data tentang gaya belajar anak dan kemampuan berbicara anak. Pengumpulan data dilakukan dengan menggunakan dua macam instrumen meliputi: (a) Instrumen berupa pedoman observasi yang digunakan untuk mengukur variabel atribut yaitu gaya belajar anak, dan (b) Instrumen berupa pedoman observasi yang digunakan untuk mengukur variabel terikat yaitu tes kemampuan berbicara anak.

Analisis yang digunakan meliputi analisis deskriptif dan analisis inferensial. Analisis deskriptif dilakukan untuk menyajikan data setiap variabel dalam besaran-besaran statistik seperti rata-rata (mean), nilai tengah (median), frekuwensi terbanyak (modus), simpangan baku (standar deviasi), dan menvisualisasikan ke dalam bentuk tabel distribusi frekuwensi dan histogram, sedangkan analisis infrensial merupakan statistik yang digunakan untuk pengujian hipotesis.

Pengujian hipotesis digunakan teknik analisis varians (ANAVA) dua jalur $2 \times 2$ pada taraf signifikan $\alpha=0,05$. Apabila uji anava terdapat pengaruh yang signifikan dari setiap faktor perlakuan dan interaksinya, dilanjutkan dengan uji Tukey. Uji hipotesis dilakukan setelah melakukan uji persyaratan analisis data yaitu menguji normalitas data yang diperoleh dari hasil penerapan metode bercerita dengan menggunakan media boneka tangan dan media power point dan gaya belajar terhadap kemampuan berbahasa lisan anak digunakan uji Liliefors. Untuk uji homogenitas menggunakan uji Barlett atau Levene Statistic pada analisis homogenitas varian data homogen jika $p>0,05$ dan tidak homogen jika $p<$ 0,05 . Jika terdapat interaksi antara metode bercerita dan gaya belajar terhadap kemampuan berbahasan lisan anak maka akan dilanjutkan dengan uji Tukey.

\section{HASIL DAN PEMBAHASAN}

\section{Kelompok Anak yang Diberi Metode Bercerita dengan Media Boneka Tangan $\left(A_{1}\right)$}

Berdasarkan pada data yang telah dikumpulkan dari responden sebanyak 22 orang anak, diperoleh data kelompok anak yang diberi metode bercerita dengan media boneka tangan dengan perolehan skor tertinggi 26 , skor terendah 17 , rata-rata 21,36 , nilai median 21 , nilai modus 19,5, dan simpangan baku 6,07.

\section{Kelompok Anak yang Diberi Metode Bercerita dengan Media Power Point $\left(\mathrm{A}_{2}\right)$}

Berdasarkan pada data yang telah dikumpulkan dari responden sebanyak 22 orang anak, diperoleh data kelompok anak yang diberi metode bercerita dengan media power point dengan perolehan skor tertinggi 23 , skor terendah 17 , rata-rata 19,73 , nilai median 19,5, nilai modus 19,5 dan simpangan baku 5,77.

\section{Kelompok Anak yang Memiliki Gaya Belajar Auditory $\left(\mathrm{B}_{1}\right)$}

Berdasarkan pada data yang telah dikumpulkan dari responden sebanyak 22 orang anak, diperoleh data kelompok anak yang memiliki gaya belajar auditory dengan perolehan skor tertinggi 26 , skor terendah 17 , rata-rata 21,50 , nilai median 22,3 , nilai modus 19,7 dan 23,3, dan simpangan baku 6,10.

\section{Kelompok Anak yang Memiliki Gaya Belajar Visual ( $\left.\mathbf{B}_{2}\right)$}

Berdasarkan pada data yang telah dikumpulkan dari responden sebanyak 22 orang anak, diperoleh data kelompok anak yang memiliki gaya belajar visual dengan perolehan skor tertinggi 23 , skor terendah 17 , rata-rata 19,64, nilai median 19,5, nilai modus 19,16, dan simpangan baku 5,73.

Kelompok Anak yang Diberi Metode Bercerita dengan Media Boneka Tangan dan yang Memiliki Gaya Belajar Auditory $\left(\mathrm{A}_{1} \mathrm{~B}_{1}\right)$

Berdasarkan pada data yang telah dikumpulkan dari responden sebanyak 11 orang anak, diperoleh data kelompok anak yang diberi metode bercerita dengan media boneka 
tangan dan yang memiliki gaya belajar auditory dengan perolehan skor tertinggi 26, skor terendah 20, rata-rata 23,36 , nilai median 24,5 , nilai modus 22,61 , dan simpangan baku 1,80.

\section{Kelompok Anak yang Diberi Metode Bercerita dengan Media Boneka Tangan dan yang Memiliki Gaya Belajar Visual $\left(\mathbf{A}_{1} \mathbf{B}_{2}\right)$}

Berdasarkan pada data yang telah dikumpulkan dari responden sebanyak 11 orang anak, diperoleh data kelompok anak yang diberi metode bercerita dengan media boneka tangan dan yang memiliki gaya belajar visual dengan perolehan skor tertinggi 22, skor terendah 17, rata-rata 19,36, nilai median 19,1, nilai modus 19, dan simpangan baku 1,50.

\section{Kelompok Anak yang Diberi Metode Bercerita dengan Media Power Point dan yang Memiliki Gaya belajar Auditory $\left(\mathrm{A}_{2} \mathrm{~B}_{1}\right)$}

Berdasarkan pada data yang telah dikumpulkan dari responden sebanyak 11 orang anak, diperoleh data kelompok anak yang diberi metode bercerita dengan media power point dan yang memiliki gaya belajar auditory dengan perolehan skor tertinggi 23, skor terendah 17, rata-rata 19,64, nilai median 19,5, nilai modus 19,3, dan simpangan baku 1,60.

\section{Kelompok Anak yang Diberi Metode Bercerita dengan Media Power Point dan yang Memiliki Gaya Belajar Visual $\left(\mathbf{A}_{2} \mathbf{B}_{2}\right)$}

Berdasarkan pada data yang telah dikumpulkan dari responden sebanyak 11 orang anak, diperoleh data kelompok anak yang diberi metode bercerita dengan media power point dan yang memiliki gaya belajar visual dengan perolehan skor tertinggi 23, skor terendah 17, rata-rata 19,91, nilai median 21, nilai modus 20,94, dan simpangan baku 1,87.

Kumpulan data kemampuan berbicara anak dari masing-masing kelompok setelah mendapat perlakuan, selanjutnya akan digunakan sebagai bahan analisis, seperti pada tabel berikut:

Tabel 1. Deskripsi Data Kemampuan Berbicara Anak

\begin{tabular}{|c|c|c|c|c|c|c|}
\hline \multirow[t]{2}{*}{ Gaya Belajar } & \multicolumn{4}{|c|}{ Metode Bercerita } & \multicolumn{2}{|r|}{ Total } \\
\hline & Medic & $\begin{array}{l}\text { a Boneka Tangan } \\
\left(\mathbf{A}_{1}\right)\end{array}$ & Med & $\begin{array}{l}\text { ia Power Point } \\
\left(\mathbf{A}_{2}\right)\end{array}$ & & \\
\hline \multirow{4}{*}{ Auditory $\left(\mathrm{B}_{1}\right)$} & $\sum n A_{1} B_{1}$ & $=11$ & \multicolumn{2}{|c|}{$\sum n A_{2} B_{1}=11$} & $\sum n B_{1}$ & $=22$ \\
\hline & & $=257$ & & $=216$ & $\sum Y$ & $=451$ \\
\hline & $\sum Y^{2}$ & $=6037$ & $\sum Y^{2}$ & $=4270$ & $\sum Y^{2}$ & $=9383$ \\
\hline & & $=22,36$ & & $=19,63$ & $\bar{x}$ & $=21,5$ \\
\hline \multirow{4}{*}{ Visual $\left(\mathrm{B}_{2}\right)$} & $\sum n A_{1} B_{2}$ & $=11$ & \multicolumn{2}{|c|}{$\sum n A_{2} B_{2}=11$} & $\sum n B_{2}$ & $=22$ \\
\hline & & $=213$ & $\sum Y$ & $=219$ & $\sum Y$ & $=410$ \\
\hline & $\bar{\sum} Y^{2}$ & $=4147$ & $\bar{\Sigma} Y^{2}$ & $=4395$ & $\bar{\sum} Y^{2}$ & $=7706$ \\
\hline & $\bar{x}$ & $=19,36$ & $\bar{x}$ & $=19,91$ & $\bar{x}$ & $=19,63$ \\
\hline \multirow{3}{*}{ Total } & $\sum n A_{1}$ & $=22$ & $\sum n A_{2}$ & $=22$ & $\sum n_{t}$ & $=44$ \\
\hline & $\begin{array}{l}\sum Y \\
\sum Y^{2}\end{array}$ & $\begin{array}{l}=448 \\
=9266\end{array}$ & $\begin{array}{l}\sum Y \\
\sum Y^{2}\end{array}$ & $\begin{array}{l}=413 \\
=7823\end{array}$ & $\begin{array}{l}\sum Y \\
\sum Y^{2}\end{array}$ & $\begin{array}{l}=905 \\
=18849\end{array}$ \\
\hline & $\bar{x}$ & $=21,36$ & $\bar{x}$ & $=19,73$ & $\bar{x}$ & $=20,26$ \\
\hline
\end{tabular}

Berdasarkan hasil perhitungan normalitas data pada semua kelompok penelitian diketahui bahwa $L_{\text {hitung }}$ untuk semua kelompok lebih kecil dari $L_{\text {tabel, }}$ ini berarti bahwa pada semua kelompok penelitian berdistribusi normal. Hasil perhitungan uji normalitas dengan uji Lilliefors secara keseluruhan dapat dilihat pada tabel berikut. 
Pengaruh Metode Bercerita dan Gaya Belajar terhadap Kemampuan Berbicara Anak usia dini

DOI: 10.31004 /obsesi.v4i1.326

Tabel 2. Rekapitulasi Hasil Uji Normalitas Sampel dengan Uji Lilliefors pada Taraf a = 0,05

\begin{tabular}{ccccc}
\hline Kelompok & Jumlah Sampel & $\begin{array}{c}\text { Lhitung } \\
\left(\mathbf{L}_{\mathbf{0}}\right)\end{array}$ & $\begin{array}{c}\text { Ltabel } \\
\left(\mathbf{L}_{\mathbf{t}} \mathbf{\alpha}=\mathbf{0}, \mathbf{0 5}\right)\end{array}$ & Kesimpulan \\
\hline $\mathbf{A}_{\mathbf{1}}$ & 22 & 0,154 & 0,19 & Normal \\
$\mathbf{A}_{\mathbf{2}}$ & 22 & 0,12 & 0,19 & Normal \\
$\mathbf{B}_{\mathbf{1}}$ & 22 & 0,13 & 0,19 & Normal \\
$\mathbf{B}_{\mathbf{2}}$ & 22 & 0,154 & 0,19 & Normal \\
$\mathbf{A}_{\mathbf{1}} \mathbf{B}_{\mathbf{1}}$ & 11 & 0,216 & 0,25 & Normal \\
$\mathbf{A}_{\mathbf{1}} \mathbf{B}_{\mathbf{2}}$ & 11 & 0,182 & 0,25 & Normal \\
$\mathbf{A}_{\mathbf{2}} \mathbf{B}_{\mathbf{1}}$ & 11 & 0,142 & 0,25 & Normal \\
$\mathbf{A}_{\mathbf{2}} \mathbf{B}_{\mathbf{2}}$ & 11 & 0,141 & 0,25 & Normal \\
\hline
\end{tabular}

Rekapitulasi dari hasil perhitungan uji homogenitas data dengan menggunakan Uji Bartlett dimana $\mathrm{X}^{2}$ hitung $\leq \mathrm{X}^{2}$ tabel pada taraf signifikansi $\alpha=0,05$ dapat dilihat pada tabel berikut:

Tabel 3. Rekapitulasi Uji Homogenitas pada Kelompok-Kelompok Penelitian Menggunakan Uji

\begin{tabular}{clccc}
\hline No & Kelompok Sampel & $\mathbf{X}^{2}$ hitung & $\begin{array}{c}\mathbf{X}^{2} \text { tabel } \\
(\mathbf{a}=\mathbf{0 , 0 5})\end{array}$ & Kesimpulan \\
\hline 1 & Kelompok $\mathrm{A}_{1}$ dan $\mathrm{A}_{2}$ & 3,52 & 3,84 & Homogen \\
2 & Kelompok $\mathrm{B}_{1}$ dan $\mathrm{B}_{2}$ & 3,63 & 3,84 & Homogen \\
3 & Kelompok $\mathrm{A}_{1} \mathrm{~B}_{1}, \mathrm{~A}_{1} \mathrm{~B}_{2}$, & 0,536 & 7,82 & Homogen \\
& $\mathrm{A}_{2} \mathrm{~B}_{1}$ dan $\mathrm{A}_{2} \mathrm{~B}_{2}$ & & & \\
\hline
\end{tabular}

Dari hasil pengujian normalitas dan homogenitas data penelitian dapat disimpulkan bahwa data berasal dari populasi yang berdistribusi normal dan homogen sehingga dapat dilanjutkan dengan pengujian hipotesis.

Berdasarkan perhitungan yang telah dilakukan secara manual menggunakan ANAVA dua jalan diperoleh analisis seperti pada tabel di bawah ini:

Tabel 4. Hasil Analisis Varians Menggunakan ANAVA Dua Jalan

\begin{tabular}{ccccccc}
\hline & \multicolumn{1}{c}{} & $\mathbf{3}$ & \multicolumn{2}{c}{$\mathbf{F}_{\text {tabel }}$} \\
Sumber varians & JK & Db & RJK & F $_{\text {hitung }}$ & $\mathbf{a = 0 , 0 5}$ & $\mathbf{a}=\mathbf{0 1}$ \\
\hline Antar A & 27,841 & 1 & 27,84 & 9,39 & 4,08 & 7,31 \\
Antar B & 38,205 & 1 & 38,20 & 12,89 & 4,08 & 7,31 \\
Interaksi A×B & 50,205 & 1 & 50,20 & 16,94 & 4,08 & 7,31 \\
Dalam (D) & 111,545 & 40 & 2,96 & & & \\
Total (T) & 234,795 & 43 & - & & & \\
\hline
\end{tabular}

Berdasarkan hasil analisis varians (ANAVA) dua jalur di atas, maka pengujian hipotesis dapat dijelaskan sebagai berikut:

a. Pengaruh Utama (Main Effect)

1) Dari hasil analisis diketahui nilai $\mathrm{F}_{(\mathrm{OA})}=9,39$. Dari tabel Daftar-G pada $\mathrm{db}(\mathrm{A}) / \mathrm{db}(\mathrm{D})$ $=1 / 40$ dan $\alpha=0,05$ diketahui nilai $\mathrm{F}_{\text {tabel }}=4,08$. Karena $\mathrm{F}_{(\mathrm{OA})}=9,39>\mathrm{F}_{\text {tabel }}=4,08$ atau $\mathrm{H}_{0}$ ditolak, jadi terdapat perbedaan rata-rata kemampuan berbicara anak antara kelompok anak yang diberi metode bercerita dengan media boneka tangan dan kelompok anak yang diberi metode bercerita dengan media power point.

2) Dari hasil analisis diketahui nilai $\mathrm{F}_{(\mathrm{OB})}=12,89$. Dari tabel Daftar-G pada $\mathrm{db}(\mathrm{A}) / \mathrm{db}(\mathrm{D})$ $=1 / 40$ dan $\alpha=0,05$ diketahui nilai $F_{\text {tabel }}=4,08$. Karena $F_{(\mathrm{OA})}=12,89>\mathrm{F}_{\text {tabel }}=4,08$ atau $\mathrm{H}_{0}$ ditolak, jadi terdapat perbedaan rata-rata kemampuan berbicara anak antara kelompok anak yang memiliki gaya belajar auditory dan kelompok anak yang memiliki gaya belajar visual. 


\section{b. Pengaruh Interaksi (Interaction Effect)}

Dari hasil analisis diketahui nilai $\mathrm{F}_{(\mathrm{OAB})}=16,94$. Dari tabel Daftar-G pada $\mathrm{db}(\mathrm{A}) / \mathrm{db}(\mathrm{D})=$ $1 / 40$ dan $\alpha=0,05$ diketahui nilai $\mathrm{F}_{\text {tabel }}=4,08$. Karena $\mathrm{F}_{(\mathrm{OA})}=16,94>\mathrm{F}_{\text {tabel }}=4,08$ atau $\mathrm{H}_{0}$ ditolak, jadi terdapat pengaruh interaksi yang signifikan antara faktor A (metode bercerita) dan faktor B (gaya belajar) terhadap kemampuan berbicara anak anak.

Dari hasil analisis terdapat interaksi, maka perlu dilakukan uji lanjut dengan uji Tukey:

Tabel 5. Rekapitulasi Hasil Perhitungan Uji Tukey

\begin{tabular}{cccc}
\hline $\begin{array}{c}\text { Kelompok } \\
\text { Perbandingan }\end{array}$ & $\mathbf{N}$ & Qhitung & $\begin{array}{c}\mathbf{Q}_{\text {tabel }} \\
(\mathbf{a}=\mathbf{0 , 0 5} \mathbf{k} \mathbf{k} \mathbf{4} ; \mathbf{n}=\mathbf{1 1})\end{array}$ \\
\hline $\mathrm{A}_{1} \mathrm{~B}_{1}$ dan $\mathrm{A}_{2} \mathrm{~B}_{1}$ & 11 & 7,18 & 4,26 \\
$\mathrm{~A}_{1} \mathrm{~B}_{2}$ dan $\mathrm{A}_{2} \mathrm{~B}_{2}$ & 11 & $-1,05$ & 4,26 \\
$\mathrm{~A}_{1} \mathrm{~B}_{1}$ dan $\mathrm{A}_{1} \mathrm{~B}_{2}$ & 11 & 7,71 & 4,26 \\
$\mathrm{~A}_{2} \mathrm{~B}_{1}$ dan $\mathrm{A}_{2} \mathrm{~B}_{2}$ & 11 & -053 & 4,26 \\
\hline
\end{tabular}

Berdasarkan hasil perhitungan yang sudah ada dilakukan, maka dapat kita simpulkan uji hipotesis sebagai berikut:

Hipotesis Pertama : Kemampuan berbicara anak pada kelompok anak yang diberi metode bercerita dengan media boneka tangan lebih tinggi dibandingkan dengan kelompok anak yang diberi metode bercerita dengan media power point.

Hipotesis ini diterima setelah didapat melalui hasil perhitungan data menggunakan ANAVA dua jalan dengan menggunakan kriteria pengujian $\mathrm{H}_{0}\left(\mathrm{H}_{0}: \mu \mathrm{A}_{1} \leq \mu \mathrm{A}_{2}\right)$ ditolak dan $\mathrm{H}_{1}\left(\mathrm{H}_{1}: \mu \mathrm{A}_{1}>\mu \mathrm{A}_{2}\right)$ diterima pada $\alpha=0,05$ berdasarkan hasil perhitungan ANAVA dua jalan diketahui bahwa nilai $\mathrm{F}_{\text {hitung }}=9,39>\mathrm{F}_{\text {tabel }}=4,08$ yang berarti $\mathrm{H}_{0}$ ditolak dan $\mathrm{H}_{1}$ diterima pada $\alpha=0,05$. Dengan demikian dapat disimpulkan bahwa kemampuan berbicara anak pada kelompok anak yang diberi metode bercerita dengan media boneka tangan lebih tinggi dari pada kemampuan berbicara anak pada kelompok anak yang diberi metode bercerita dengan media power point.

Hipotesis Kedua: Kemampuan berbicara anak Pada Kelompok Anak Yang Memiliki Gaya belajar Auditory Lebih Tinggi Daripada Kelompok Anak Yang Memiliki Gaya belajar Visual

Hipotesis ini diterima setelah didapat melalui hasil perhitungan data menggunakan ANAVA dua jalan dengan menggunakan kriteria pengujian $\mathrm{H}_{0}\left(\mathrm{H}_{0}: \mu \mathrm{B}_{1} \leq \mu \mathrm{B}_{2}\right)$ ditolak dan $\mathrm{H}_{1}\left(\mathrm{H}_{1}: \mu \mathrm{B}_{1}>\mu \mathrm{B}_{2}\right)$ diterima pada $\alpha=0,05$ berdasarkan hasil perhitungan ANAVA dua jalan diketahui bahwa nilai $\mathrm{F}_{\text {hitung }}=12,89>\mathrm{F}_{\text {tabel }}=4,08$ yang berarti $\mathrm{H}_{0}$ ditolak dan $\mathrm{H}_{1}$ diterima pada $\alpha=0,05$. Dengan demikian dapat disimpulkan bahwa kemampuan berbicara anak pada kelompok anak yang memiliki gaya belajar Auditory lebih tinggi daripada kemampuan berbicara anak kelompok anak yang memilki gaya belajar Visual.

Hipotesis Ketiga: Terdapat pengaruh interaksi antara metode bercerita dan gaya belajar terhadap kemampuan berbicara anak.

Hipotesis ini diterima setelah didapat melalui hasil perhitungan data menggunakan ANAVA dua jalan dengan menggunakan kriteria pengujian $\mathrm{H}_{0}\left(\mathrm{H}_{0}: \mathrm{A} \times \mathrm{B}=0\right)$ ditolak dan $\mathrm{H}_{1}\left(\mathrm{H}_{1}: \mathrm{A} \times \mathrm{B} \neq 0\right)$ diterima pada $\alpha=0,05$ berdasarkan hasil perhitungan ANAVA dua jalan diketahui bahwa nilai $\mathrm{F}_{\text {hitung }}=16,94>\mathrm{F}_{\text {tabel }}=4,08$ yang berarti $\mathrm{H}_{0}$ ditolak dan $\mathrm{H}_{1}$ diterima pada $\alpha=0,05$. Berarti terdapat interaksi yang signifikan antara metode bercerita dan gaya belajar terhadap kemampuan berbicara anak. Interaksi antara metode bercerita dan gaya belajar terhadap kemampuan berbicara anak dapat dilihat pada grafik berikut ini: 


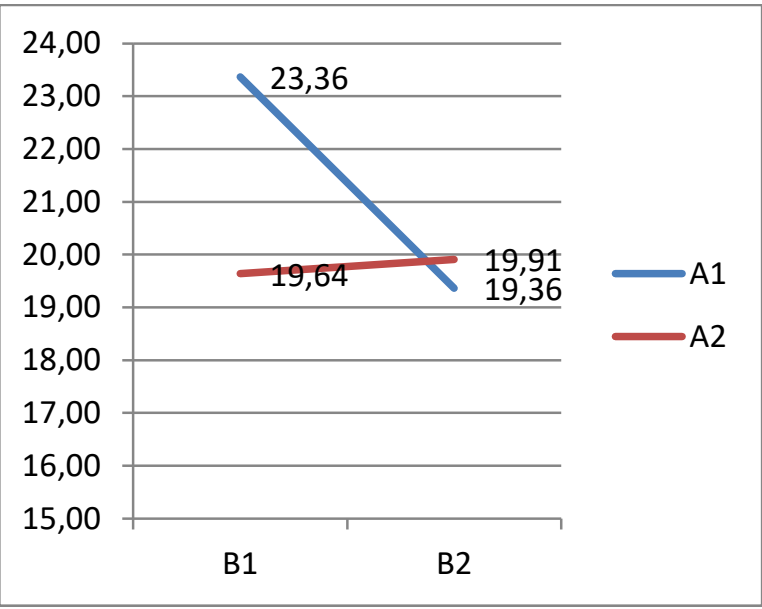

Gambar 1. Grafik Interaksi metode bercerita dan Gaya belajar terhadap Kemampuan berbicara anak

Hipotesis Keempat: Kemampuan berbicara anak pada kelompok anak yang memiliki gaya belajar auditory dan yang diberi metode bercerita dengan media boneka tangan lebih tinggi dibandingkan dengan kelompok anak diberi metode bercerita dengan media power point.

Hipotesis ini diterima setelah didapat melalui hasil perhitungan data menggunakan ANAVA dua jalan dengan menggunakan kriteria pengujian $\mathrm{H}_{0}\left(\mathrm{H}_{0}: \mu \mathrm{A}_{1} \mathrm{~B}_{1} \leq \mu \mathrm{A}_{2} \mathrm{~B}_{1}\right)$ ditolak dan $\mathrm{H}_{1}\left(\mathrm{H}_{1}: \mu \mathrm{A}_{1} \mathrm{~B}_{1}>\mu \mathrm{A}_{2} \mathrm{~B}_{1}\right)$ diterima pada $\alpha=0,05$. Selain itu skor rata-rata kemampuan berbicara anak pada anak yang diberikan metode bercerita dan yang memiliki gaya belajar auditory $\left(\mathrm{A}_{1} \mathrm{~B}_{1}\right)$ sebesar 22,36 lebih tinggi daripada skor rata-rata kemampuan berbicara anak pada anak yang diberi metode bercerita dengan media power point dan yang memiliki gaya belajar auditory $\left(\mathrm{A}_{2} \mathrm{~B}_{1}\right)$ sebesar 19,64. Sehingga berdasarkan hasil perhitungan uji lanjut dengan uji Tukey diperoleh nilai $Q_{\text {hitung }}=7,18>Q_{\text {tabel }}=4,26$ yang berarti bahwa $\mathrm{H}_{0}$ ditolak dan $\mathrm{H}_{1}$ diterima pada $\mathrm{a}=0,05$.

Dengan demikian dapat disimpulkan bahwa kemampuan berbicara anak pada kelompok anak yang diberi metode bercerita dengan media boneka tangan dan yang memiliki gaya belajar auditory lebih tinggi daripada kemampuan berbicara anak pada kelompok anak yang diberi metode bercerita dengan media power point dan yang memiliki gaya belajar auditory.

Hipotesis Kelima: Kemampuan berbicara anak pada kelompok anak yang memiliki gaya belajar visual yang diberi metode bercerita dengan media boneka tangan lebih rendah dibandingkan dengan kelompok anak yang diberi metode bercerita dengan media power point.

Hipotesis ini diterima setelah didapat melalui hasil perhitungan data menggunakan ANAVA dua jalan dengan menggunakan kriteria pengujian $\mathrm{H}_{0}\left(\mathrm{H}_{0}: \mu \mathrm{A}_{1} \mathrm{~B}_{2} \geq \mu \mathrm{A}_{2} \mathrm{~B}_{2}\right)$ ditolak dan $\mathrm{H}_{1}\left(\mathrm{H}_{1}: \mu \mathrm{A}_{1} \mathrm{~B}_{2}<\mu \mathrm{A}_{2} \mathrm{~B}_{2}\right)$ diterima pada $\alpha=0,05$. Selain itu skor rata-rata kemampuan berbicara anak pada anak yang diberikan metode bercerita dengan media boneka tangan dan yang memiliki gaya belajar visual $\left(\mathrm{A}_{1} \mathrm{~B}_{2}\right)$ sebebsar 19,36 lebih rendah dari pada skor ratarata kemampuan berbicara anak pada anak yang diberi metode bercerita dengan media power point dan yang memiliki gaya belajar visual $\left(\mathrm{A}_{2} \mathrm{~B}_{2}\right)$ sebesar 19,91 . Sehingga berdasarkan hasil perhitungan uji lanjut dengan uji Tukey diperoleh nilai $Q_{\text {hitung }}=-1,05<Q_{\text {tabel }}=4,26$ yang berarti bahwa $\mathrm{H}_{0}$ ditolak dan $\mathrm{H}_{1}$ diterima pada $\mathrm{a}=0,05$.

Dengan demikian dapat disimpulkan bahwa kemampuan berbicara anak pada kelompok anak yang diberi metode bercerita dengan media boneka tangan dan yang memiliki gaya belajar visual lebih rendah daripada kemampuan berbicara anak pada kelompok anak yang diberi metode bercerita dengan media power point dan yang memiliki gaya belajar visual. 
Hipotesis Keenam: Kemampuan berbicara anak pada kelompok anak yang memiliki gaya belajar Auditory yang metode bercerita dengan media boneka tangan lebih tinggi dibandingkan dengan kelompok anak yang yang memiliki gaya belajar Visual yang diberi metode bercerita media boneka tangan.

Hipotesis ini diterima setelah didapat melalui hasil perhitungan data menggunakan ANAVA dua jalan dengan menggunakan kriteria pengujian $\mathrm{H}_{0}\left(\mathrm{H}_{0}: \mu \mathrm{A}_{1} \mathrm{~B}_{1} \geq \mu \mathrm{A}_{1} \mathrm{~B}_{2}\right)$ ditolak dan $\mathrm{H}_{1}\left(\mathrm{H}_{1}: \mu \mathrm{A}_{1} \mathrm{~B}_{1}<\mu \mathrm{A}_{1} \mathrm{~B}_{2}\right)$ diterima pada $\alpha=0,05$. Selain itu skor rata-rata kemampuan berbicara anak pada anak yang diberikan metode bercerita dengan media boneka tangan dan yang memiliki gaya belajar auditory $\left(\mathrm{A}_{1} \mathrm{~B}_{1}\right)$ sebebsar 23,36 lebih tinggi dari pada skor rata-rata kemampuan berbicara anak pada anak yang diberi metode bercerita dengan media boneka tangan dan yang memiliki gaya belajar visual $\left(\mathrm{A}_{1} \mathrm{~B}_{2}\right)$ sebesar 19,36. Sehingga berdasarkan hasil perhitungan uji lanjut dengan uji Tukey diperoleh nilai $Q_{\text {hitung }}=7,71>Q_{\text {tabel }}$ = 4,26 yang berarti bahwa $\mathrm{H}_{0}$ ditolak dan $\mathrm{H}_{1}$ diterima pada $\mathrm{\alpha}=0,05$.

Dengan demikian dapat disimpulkan bahwa kemampuan berbicara anak pada kelompok anak yang diberi metode bercerita dengan media boneka tangan dan yang memiliki gaya belajar auditory lebih tinggi daripada kemampuan berbicara anak pada kelompok anak yang diberi metode bercerita dengan media boneka tangan dan yang memiliki gaya belajar visual.

Hipotesis Ketujuh: Kemampuan berbicara anak pada kelompok anak yang memiliki gaya belajar Auditory yang diberi metode bercerita dengan media power point lebih rendah dibandingkan dengan kelompok anak yang memiliki gaya belajar Visual yang diberi metode bercerita dengan media power point.

Hipotesis ini diterima setelah didapat melalui hasil perhitungan data menggunakan ANAVA dua jalan dengan menggunakan kriteria pengujian $\mathrm{H}_{0}\left(\mathrm{H}_{0}: \mu \mathrm{A}_{2} \mathrm{~B}_{1} \geq \mu \mathrm{A}_{2} \mathrm{~B}_{2}\right)$ ditolak dan $\mathrm{H}_{1}\left(\mathrm{H}_{1}: \mu \mathrm{A}_{2} \mathrm{~B}_{1}<\mu \mathrm{A}_{2} \mathrm{~B}_{2}\right)$ diterima pada $\alpha=0,05$. Selain itu skor rata-rata kemampuan berbicara anak pada anak yang diberikan metode bercerita dengan media power point dan yang memiliki gaya belajar auditory $\left(\mathrm{A}_{2} \mathrm{~B}_{1}\right)$ sebebsar 19,63 lebih rendah dari pada skor ratarata kemampuan berbicara anak pada anak yang diberi metode bercerita dengan media power point dan yang memiliki gaya belajar visual $\left(\mathrm{A}_{2} \mathrm{~B}_{2}\right)$ sebesar 19,90 . Sehingga berdasarkan hasil perhitungan uji lanjut dengan uji Tukey diperoleh nilai $Q_{\text {hitung }}=-0,53<Q_{\text {tabel }}=4,26$ yang berarti bahwa $\mathrm{H}_{0}$ ditolak dan $\mathrm{H}_{1}$ diterima pada $\alpha=0,05$.

Dengan demikian dapat disimpulkan bahwa kemampuan berbicara anak pada kelompok anak yang diberi metode bercerita dengan media power point dan yang memiliki gaya belajar auditory lebih rendah daripada kemampuan berbicara anak pada kelompok anak yang diberi metode bercerita dengan media power point dan yang memiliki gaya belajar visual.

\section{SIMPULAN}

Berdasarkan hasil penelitian dan pembahasan diperoleh kesimpulan bahwa terdapat pengaruh interaksi antara metode bercerita dan gaya belajar terhadap kemampuan berbicara anak. Artinya untuk meningkatkan kemampuan berbicara anak maka penerapan metode bercerita harus disesuaikan dengan gaya belajar anak. Anak dengan gaya belajar auditory yang diajarkan menggunakan metode bercerita dengan boneka tangan kemampuan berbicaranya lebih tinggi daripada anak yang diajarkan menggunakan metode bercerita dengan media power point. Artinya untuk meningkatkan kemampuan berbicara anak, anak yang gaya belajarnya auditory lebih tepat digunakan metode bercerita dengan boneka tangan. Kemudian anak dengan gaya belajar visual yang diajarkan menggunakan metode bercerita dengan boneka tangan kemampuan berbicaranya lebih rendah daripada anak yang diajarkan menggunakan metode bercerita dengan media power point. Itu berarti untuk meningkatkan kemampuan berbicara anak, anak yang gaya belajarnya visual lebih tepat 
DOI: 10.31004 /obsesi.v4i1.326

digunakan metode bercerita dengan media power point. Selanjutnya anak yang diajarkan menggunakan metode bercerita dengan media boneka tangan, yang memiliki gaya belajar auditory kemampuan berbicaranya lebih tinggi daripada anak yang memiliki gaya belajar visual. Artinya untuk meningkatkan kemampuan berbicara anak, anak yang memiliki gaya belajar auditory, lebih tepat digunakan metode bercerita dengan media boneka tangan. Selanjutnya anak yang diajarkan menggunakan metode bercerita dengan media power point, yang memiliki gaya belajar visual kemampuan berbicaranya lebih tinggi daripada anak yang memiliki gaya belajar auditory. Artinya untuk meningkatkan kemampuan berbicara anak, anak yang memiliki gaya belajar visual lebih tepat digunakan metode bercerita dengan media power point. Berdasarkan uraian di atas, dapat disimpulkan bahwa metode bercerita dan gaya belajar berpengaruh terhadap kemampuan berbicara anak. Oleh karena itu, untuk meningkatkan kemampuan berbicara anak, penggunaan metode bercerita dan gaya belajar yang dimiliki anak sangat membantu.

\section{DAFTAR PUSTAKA}

Affrida, E. N. (2017). Jurnal Obsesi : Jurnal Pendidikan Anak Usia Dini Strategi Ibu dengan Peran Ganda dalam Membentuk Kemandirian Anak. 1(2), 124-130. https://doi.org/10.31004/obsesi.v1i2.24

Ananda, R. (2017). Implementasi Nilai-nilai Moral dan Agama pada Anak Usia Dini. Jurnal Obsesi : Jurnal Pendidikan Anak Usia Dini, 1(1), 19-31. https://doi.org/10.31004/obsesi.v1i1.28

Hasanah, A., \& Muryanti, E. (2019). Pengaruh Penggunaan Media Diorama terhadap Perkembangan Kemampuan Motorik Halus Anak Usia Dini. Aulad : Journal on Early Childhood, 2(2), 1-7. https:/ / doi.org/10.31004/aulad.v2i2.29

Hurlock, E. B. (1978). Perkembangan Anak Jilid 1. (Alih Bahasa: Meitasari Tjandra \& Muslichah Zarkasih). Jakarta: Penerbit Erlangga.

JR, R. R., Luthfi, A., \& Fauziddin, M. (2018). Pengaruh Metode Bercerita terhadap Kemampuan Menyimak pada Anak Usia Dini. Aulad: Journal on Early Childhood, 1(1), 39-51. https://doi.org/10.31004/aulad.v1i1.5

Nengsi, M. I., \& Eliza, D. (2019). Pelaksanaan Pengembangan Karakter Peduli Lingkungan Bagi Anak dalam Konteks Alam Takambang Jadi Guru. Aulad: Journal on Early Childhood, 2(2), 28-40. https:/ / doi.org/10.31004/aulad.v2i2.32

Pebriana, P. H. (2017). Analisis Kemampuan Berbahasa dan Penanaman Moral pada Anak Usia Dini melalui Metode Mendongeng. 1(2), 139-147. https://doi.org/10.31004/obsesi.v1i2.25

R, M. (2004). Metode Pengajaran di Taman Kanak-kanak. Jakarta: Rineka Cipta.

Suhartono. (2005). Pengembangan Keterampilan Bicara Anak Usia Dini. Departemen Pendidikan dan Kebudayaan, Direktorat Jenderal Pendidikan Tinggi, Direktorat Pembinaan Pendidikan Tenaga Pendidikan dan Ketenagaan Perguruan Tinggi.

Sumarsih, S., Nurmalina, N., \& Astuti, A. (2018). Meningkatkan Kemampuan Kognitif dalam Mengenal Warna dengan Metode Eksperimen. Aulad: Journal on Early Childhood, 1(1), 72-77. https://doi.org/10.31004/aulad.v1i1.8

Zubaidah, E. (2005). Pengembangan Bahasa Anak Usia Dini. Yogyakarta: FIP UNY. 